\title{
SOME INEQUALITIES FOR COSINE SUMS
}

\section{STAMATIS KOUMANDOS}

Abstract. We establish sharp lower and upper estimates for the cosine sums $\sum_{k=1}^{n} \frac{\cos k \theta}{k+1}$. We also discuss the possibility of extending these results to other cosine sums of this type.

Mathematics subject classification (2000): 42A05, 42A32.

Key words and phrases: Cosine sums, Fourier series.

\section{REFERENCES}

[1] A. S. BELOV, Examples of trigonometric series with nonnegative partial sums. (Russian) Math. Sb. 186 no 4, (1995), 21-46; (English translation) 186, no 4, (1995), 485-510.

[2] G. BRown AND E. HewITt, A class of positive trigonometric sums, Math. Ann. 268 (1984), 91-122.

[3] G. BRown AND S. Koumandos, On a monotonic trigonometric sum, Monatsh. für Math. 123 (1997), $109-119$.

[4] G. GASPER, Nonnegative sums of cosine, ultraspherical and Jacobi polynomials, J. Math. Anal. Appl. 26 (1969), 60-68.

[5] C. Hyltén-CAvallius, Geometrical methods applied to trigonometrical sums. Kungl. Fysiografiska Sällskapets i Lund Förhandlingar 21 (1950), 1-19.

[6] G. V. Milovanović, D. S. MitrinoviĆ AND TH. M. Rassias, Topics in polynomials. Extremal problems, inequalities, zeros. World Scientific, 1994.

[7] A. P. PRUDNIKOV, YU. A. BRYCHKOV AND O. I. MARICHEV, Integrals and Series, Gordon Breech Science Publishers, 1990.

[8] W. RogosinsKI AND G. SZEGŐ , Über die Abschnitte von Potenzreihen die in einem Kreise beschrankt bleiben. Math. Zeit. 28 (1928), 73-94.

[9] M. Tomić, On Fejér's polynomials, Glas Srpske AN 232 (1958), $29-44$.

[10] W. H. Young, On certain series of Fourier. Proc. London Math. Soc. (2) 11 (1912), 357-366. 